\title{
Tourism Sector Development in Belitung Regency: The Tourist's Perception
}

\author{
Devi Valeriani ${ }^{1, *}$ (D) and Aning Kesuma Putri ${ }^{1}$ \\ ${ }^{1}$ Department of Economics, Faculty of Economics, \\ University of Bangka Belitung, 33172, Bangka Belitung Islands Province, Indonesia \\ *Corresponding Author: deviyono92@gmail.com
}

\section{ARTICLE INFO}

\section{Publication Info:}

Research Article

How to cite:

Valeriani, D., E Putri, A. K.

(2020). Tourism Sector

Development in Belitung Regency:

The Tourist's Perception. Society, 8(1), 109-122.

DOI : 10.33019/society.v8i1.157

Copyright (C) 2020. Owned by Author(s), published by Society

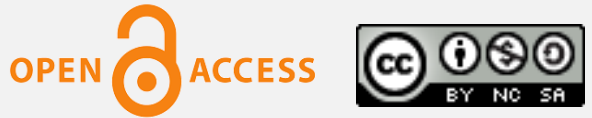

This is an open-access article.

\section{License: Attribution- \\ NonCommercial-ShareAlike (CC BY-NC-SA)}

Received: March 4, 2020;

Accepted: April 22, 2020;

Published: April 30, 2020;

\section{ABSTRACT}

Tourism has the potential to be developed into a leading sector in Belitung Regency. The development of tourism is indicated by the increasing number of tourists, both domestic and foreign tourists from 2015 to 2018 by 85.9\% over 4 years. This research aims to determine the gap between the level of satisfaction and the importance of supporting components of tourism to tourists who visited tourist destinations in Belitung Regency. This research was quantitative research using Importance Performance Analysis. Primary data obtained by interview through the Likert scale questions. The subjects in this research were 400 domestic tourists and 400 foreign tourists. The subjects were selected using Slovin's Formula sampling techniques. Tourism support components consisting of prices, physical facilities (infrastructures), and guarantees (services) were used to determine tourist perceptions about the level of satisfaction and importance. The results of the research showed that domestic tourists were dissatisfied with component 1) guarantees (services) consisting of cultural attractions, public communication and services officers, as well as 2) physical facilities (infrastructures) consisting of souvenir galleries, toilets, environmental cleanliness, restaurant cleanliness, and safety facilities. While foreign tourists have a low level of satisfaction with the service of the officers and the public in terms of communicating in foreign languages, cultural attractions, and environmental cleanliness.

\section{Keywords: Guarantee; IPA; Physical Facilities; Price;} Tourist

Copyright (C) 2020. Owned by Author(s), published by Society. This is an open-access article under the CC-BY-NC-SA license. 


\section{Introduction}

The tourism potential in the Bangka Belitung Islands Province especially in Belitung Regency has been very well known by tourists, both domestic and foreign. This is indicated by a significant increase in tourist visits from 2015 to 2018 over 4 years. The number of foreign tourist visits has increased by $234.6 \%$ and domestic tourist visits increased by $83.3 \%$. The total increase of tourists visiting Belitung Regency was $85.9 \%$, with details as shown in the following figure:

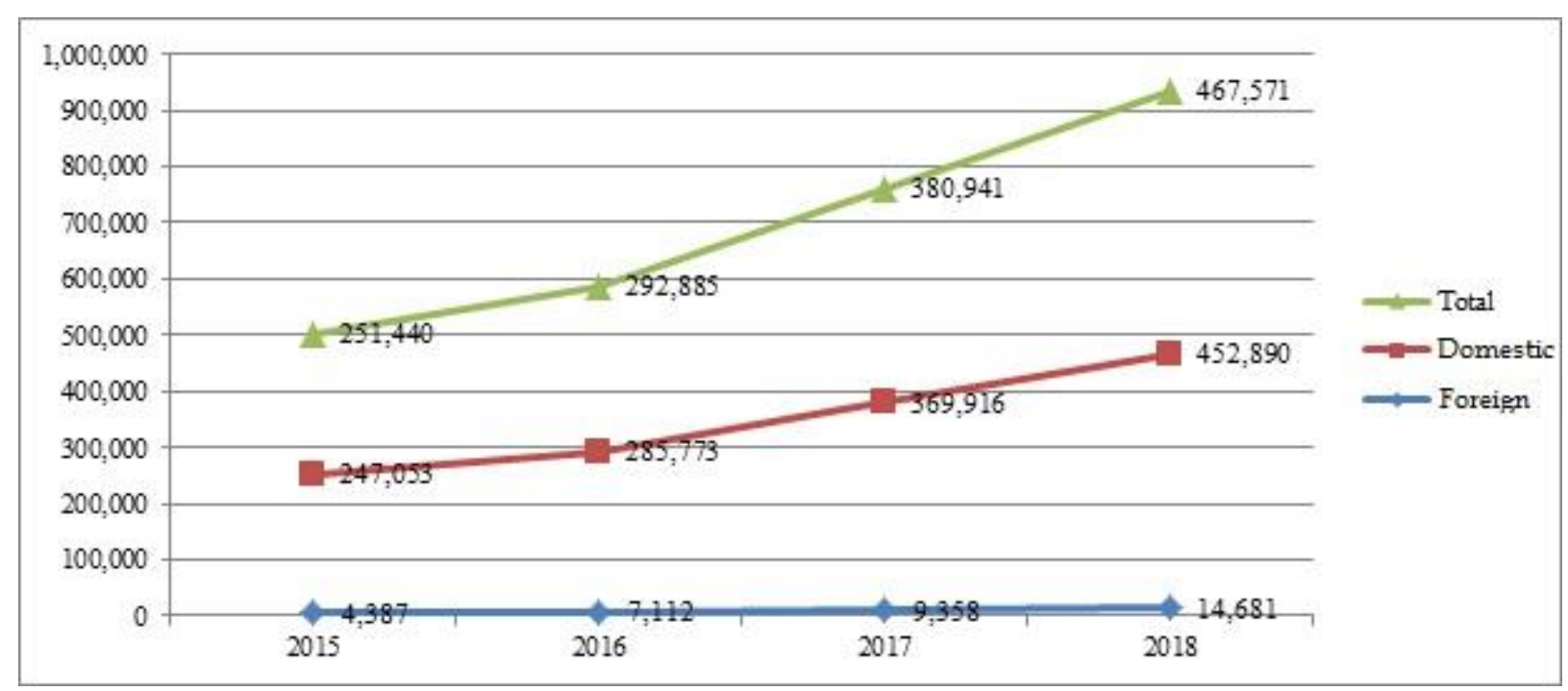

Figure 1. Tourist Visits to Belitung Regency in 2015 - 2018

Source: Primary Data (2019)

Tourist visits which have increased require efforts to improve the quality of tourist destinations and adequate supporting components each year. It is assumed that global conditions affecting tourist visits are considered normal. To increase tourist visit rates, local governments need to know the factors or conditions that affect the level of tourist satisfaction. Besides the level of satisfaction, it also needs to know the importance of each supporting factor that can affect tourist visits and satisfaction (Kleeman, 2001; Rajesh, 2013; Valeriani \& Wardhani, 2015; Haarhoff, 2018).

The results of the initial survey showed that $93 \%$ of tourists visiting Belitung are due to the beauty of the white sand beaches, large granite rocks, and also natural seawater. Just relying on natural beauty is not enough, but it requires other supporting tourism components such as price, condition of physical facilities (infrastructures), and guarantees (services). These components will be tested to determine the level of satisfaction and importance of tourists. An analysis using Importance Performance Analysis (IPA) is needed to determine the level of satisfaction and the importance of supporting components for tourists (Wong et al., 2011; De Nisco et al., 2015; Kasnadi \& Indrayani, 2019). This analysis is a simple implementation technique to know the level of satisfaction and importance of tourists when visiting so it is useful for tourism development in Belitung Regency (Valeriani et al., 2017; Andriani, 2019). The ability to provide a high-quality and satisfying tourist experience is an important source of competitive advantage. This is very important due to the increasing competition between domestic and international tourist destinations.

Some studies have been conducted on the perception of tourist-related to the level of tourist satisfaction. De Nisco et al., (2015) showed that tourists while visiting want an attraction of historical heritage. Other studies have found that satisfactory tourism experiences can affect the

Copyright (C) 2020. Owned by Author(s), published by Society. This is an open-access article under the CC-BY-NC-SA license. https://doi.org/10.33019/society.v8i1.157 
intention of post-visit behavior, such as the intention to return to visit the destination (Chen \& Tsai, 2007) and willingness to recommend it (Bigné et al., 2001; Chi \& Qu, 2008). Tourists will make a comparison between visited tourist destinations and previously visited. The difference becomes a point of comparison to evaluate tourist satisfaction (Armario, 2008; Alegre \& Garau, 2010; Aliman et al., 2016).

There is a need for research to know the difference between overall satisfaction on tourist destinations and satisfaction related to tourism support components such as hotels, restaurants, shops, transportation, and so on (Butcher, 2002; Ryglova et al., 2015). Therefore, besides the functional components, many contextual and environmental factors contribute to the perception of tourism experiences, such as social factors, the quality of human interactions that lead to benefits and responses to experiences and physical environments such as nature, attractions, landscaping and so on (Fuchs \& Weiermair, 2003).

This research aims to determine the gap between the level of satisfaction and the importance of tourists who visited tourist destinations in the Belitung Regency by using Importance Performance Analysis (IPA). Tourism support components consisting of prices, physical facilities (infrastructures), and guarantees (services) were used to determine tourist perceptions about satisfaction and the importance of tourists to determine tourism development strategy.

\section{Literature Review}

\subsection{The Concept of Tourism}

Tourism is an activity to visit a place to get pleasure, look for satisfaction, knowing something, improving health, enjoying sports or resting, fulfilling tasks, pilgrimages, and others (Aynalem et al., 2016; Camilleri, 2018). Whereas Zaei \& Zaei (2013) defined tourism as an organization, both government and private, involved in the development, production, and marketing of a service product, which fulfills the needs of people who are traveling. Also, Gunawan et al., (2016) explained that tourism is one of the new industries that can encourage employment opportunities, income, living standards, and activate other production sectors in tourist receiving countries. Tourism can encourage the development of the domestic economic sector, such as tourism services, which consist of transportation and accommodation businesses (hotels, motels, tourist cottages) (Bertan \& Altintaş, 2013).

Tourism can create and expand new jobs such as hotels or other lodgings, travel businesses, government offices in tourism, translator offices, handicraft, and souvenir industries, and sales galleries, and encourage the development of areas that have tourism attractions (Ariya et al., 2017). The developments of tourism have the potential to develop regional tourism destinations. This potential affects the motivation of tourists to visit Tourist Attraction (Leung et al., 2018).

\subsection{Tourist Attraction}

Based on the Law of the Republic of Indonesia Number 10 of 2009, Tourist Attractions is something that has a uniqueness, convenience, and value consisting of a diversity of natural wealth, culture, and human-made products, which are targeted or visited by tourists (Republik Indonesia, 2009). Another definition reveals that Tourist Attraction is anything that becomes an attraction for people to visit a certain area (Vengesayi et al., 2009). Tourist Attractions as well as anything interesting and valuable to visit and see (Devy \& Soemanto, 2017).

Tourism Attractions are divided into three types, consisting of (1) Natural Tourist Attractions, (2) Cultural Tourist Attractions, and (3) Special Interest Tourist Attractions. Natural Tourist Attraction is a Tourist Attraction developed based on the beauty and uniqueness of 
nature, such as beaches, sea, lakes, and others. Cultural Tourist Attraction is a Tourist Attraction developed based on the work and creation of humans, both cultural heritage (sites) and cultural values that still exist in a community (the living culture), such as ceremonies/rituals, customs, performing arts, craft arts, literary arts, fine arts, or daily uniqueness owned by a community. Special Interest Tourist Attraction is a Tourist Attraction developed based on activities to fulfill specific tourist interests such as fishing, shopping, golf (sport), agro-tourism, and others (Kementerian Pariwisata Republik Indonesia, 2018; Manafe et al., 2016).

\subsection{Tourism Actor}

Tourism actors are all parties who play a role and are involved in tourism activities (Molina et al., 2010; Räikkönen, 2014), which consists of:

1) Tourists, consumers, or users of travel products and services. Tourists have a variety of motives and backgrounds (interests, expectations, social, economic, cultural characteristics) to visit/travel. Tourists consist of domestic and foreign tourists (Tureac \& Turtureanu, 2010).

2) Tourism Industry/Service Providers, all businesses that produce goods and services for tourism.

3) Supporting Tourism Services, businesses that do not specifically offer tourism products and services but often depend on tourists as users of these services and products.

4) The government, the party that has the authority in regulating, supplying, and allocating various infrastructure related to tourism.

5) The local community, people who live around the tourist area. The local community is one of the important actors in tourism who acts as a provider of most attractions and also a determining factor for the quality of tourism products.

\subsection{Tourism Infrastructure}

The development of the tourism sector is strongly related and depends on the development of infrastructure. Infrastructure systems defined as facilities or basic structures, equipment, installations, which are constructed and are needed and important for the functioning of social systems and economic systems of the community (Panasiuk, 2007). Infrastructure development is very important which will encourage the development of the tourism sector (Blazeska et al., 2018).

\subsection{Tourism Marketing}

Tourism marketing is a process of management conducted by the organization and industry through communication to determine and influence the interest, needs, motivation, likes and dislikes on local, national and international areas, then formulate and customize the tourism products to achieve the maximum satisfaction of tourists and benefit from the satisfaction of the tourists (Utama, 2016). The objectives of tourism marketing are (1) attracting tourists to visit an area, (2) attracting tourists to use the services provided by the tourism industry.

\subsection{Tourist Satisfaction}

Several studies have discussed tourist satisfaction and stated that it is necessary to consider the local potential or specificity of the tourism sector in each region to measure tourist satisfaction (Bowen, 2002; Fuchs \& Reichel, 2006; Chi, 2011; Gursoy et al., 2013). 


\section{Research Methodology}

This research was quantitative research using Importance Performance Analysis (IPA). This research was conducted in August - November 2019. Data collection techniques used in this research were interviews, observation, and literature studies. Primary data obtained by interview through the Likert scale questions. The subjects in this research were 400 domestic tourists and 400 foreign tourists. The subjects were selected using Slovin's Formula sampling techniques.

\subsection{Importance Performance Analysis (IPA)}

The use of the Importance Performance Analysis (IPA) method in the tourism sector is a scheme that is in line with the performance expectation approach and its use has been done in tourism marketing (Bindu \& Kanagaraj, 2013; De Nisco et al., 2015; Jeng et al., 2019). Importance Performance Analysis (IPA) was used to measure the level of individual satisfaction with the importance of other parties. Importance Performance Analysis (IPA) has also been used to evaluate hotel performance and tourism events (Chu \& Choi, 2000; Beldona \& Cobanoglu, 2007; Wilkins, 2010; Djeri et al., 2018). Recently, Sörensson \& von Friedrichs (2013) and Boley et al., (2017) used Importance Performance Analysis (IPA) to compare the performance of tourism destinations related to social and environmental sustainability. The individual satisfaction is measured by comparing the level of satisfaction with the level of importance. Measurement of the value of alternative values of satisfaction and importance level is done with Likert scale as follows:

\section{Table 1. The Alternative Values of Satisfaction and Importance Level}

\begin{tabular}{|ccc|}
\hline Satisfaction Level & Score Value & Importance Level \\
\hline Very Satisfied & $\mathbf{5}$ & Very Important \\
Satisfied & $\mathbf{4}$ & Important \\
Quite Satisfied & $\mathbf{3}$ & Quite Important \\
Dissatisfied & $\mathbf{2}$ & Not Important \\
Very Dissatisfied & $\mathbf{1}$ & Very Unimportant \\
& Source: Budiaji (2013) & \\
\hline
\end{tabular}

This technique directs respondents to an assessment of their level of satisfaction and importance. The average value of the satisfaction and importance are then analyzed using the Importance-Performance Matrix, where the X-axis represents satisfaction while the Y-axis represents importance. The result will be the four quadrants according to the following figure:

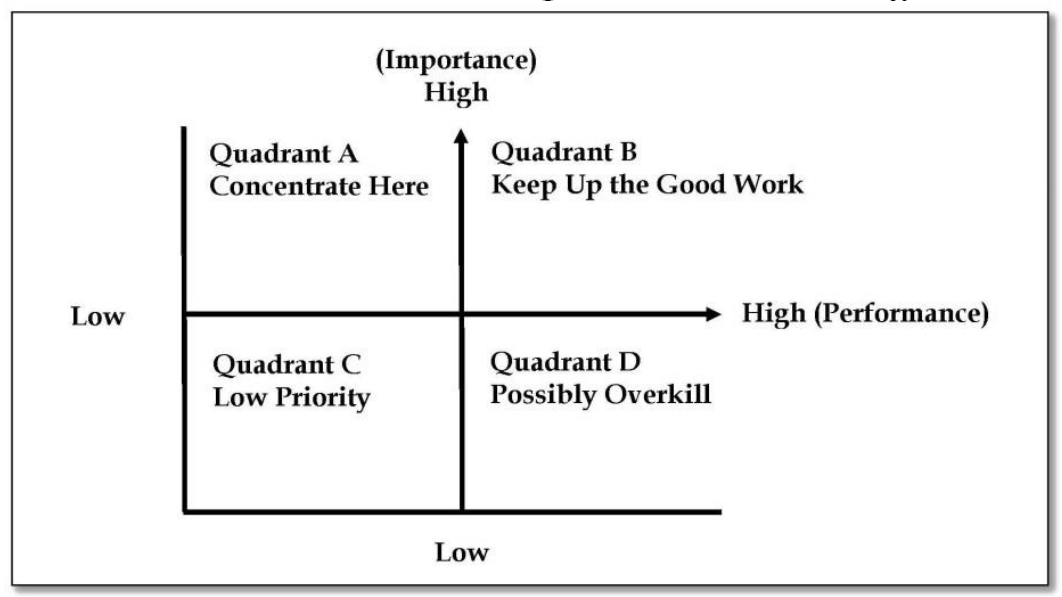

Figure 2. The Quadrants of Importance Performance Analysis (IPA) Source: De Nisco et al., (2015); Djeri et al., (2018)

Copyright (C 2020. Owned by Author(s), published by Society. This is an open-access article under the CC-BY-NC-SA license. https://doi.org/10.33019/society.v8i1.157 
The interpretation of the quadrant based on Djeri et al., (2018) are:

A. Concentrate Here: At this quadrant, the factors that consumers enjoy have high importance but low satisfaction, so the factors in this quadrant become the main priority for the management.

B. Keep Up the Good Work: In this quadrant, the factors that consumers enjoy have high importance and satisfaction, so the management does not need to concentrate on the improvement, but it needed to maintain the factors.

C. Low Priority: In this quadrant, the factors that consumers enjoy have low importance and satisfaction. After the main priority has improved, the factors in this quadrant must be the next main priority.

D. Possibly Overkill: In this quadrant, the factors that consumers enjoy have low importance but high satisfaction. The management is too excessive in paying attention to the factors.

The results of the mapping of the Importance Performance Analysis (IPA) quadrants mean that the factors in quadrant A are the priority, which must be fulfilled, developed, or built in advance. The next steps are development on factors in quadrant $\mathrm{C}$.

\subsection{Population and Sample}

The population is general and refers to entities such as people, companies, cities, countries, and so on, which are used as statistical and econometric analysis tools (Gujarati, 2003). The populations in this research were 452,890 domestic tourists and 14,681 foreign tourists. The sample is a portion of the population, which has the same properties as the object, which is the source of the data (Firman, 2018).

Sampling is the consideration of efficiency and leads to the centralization of the problem by focusing on a portion of its population. The sample determination of this research using the Slovin Formula (Gujarati, 2003), as follows:

$$
\mathrm{n}=\frac{N}{N \cdot d^{2}+1}
$$

$\mathrm{n}=$ size of the sample from a population

$N=$ size of a population

$d=$ margin of error

Calculation of sample of domestic tourists:

$$
\begin{gathered}
\mathrm{n}=\frac{N}{N . d^{2}+1} \\
\mathrm{n}=\frac{452.890}{452.890 \times 0.05^{2}+1}=399.6
\end{gathered}
$$

Calculation of sample of foreign tourists:

$$
\begin{gathered}
\mathrm{n}=\frac{N}{N . d^{2}+1} \\
\mathrm{n}=\frac{14.681}{14.681 \times 0.05^{2}+1}=389.4
\end{gathered}
$$

Copyright (C 2020. Owned by Author(s), published by Society. This is an open-access article under the CC-BY-NC-SA license. https://doi.org/10.33019/society.v8i1.157 
Based on this formula, a total sample of 399 domestic tourists and 389 foreign tourists were obtained, and then the results were rounded to 400 for each sample.

\section{Results and Discussion}

\subsection{Results of Importance Performance Analysis (IPA) on Domestic Tourists}

This research divided components into 3 types, consisting of prices, physical facilities (infrastructures), and guarantees (services), with the questionnaire and quadrants, arranged based on the results of the Importance Performance Analysis (IPA) analysis. Based on a questionnaire distributed to domestic tourists as respondents, the results obtained are as follows:

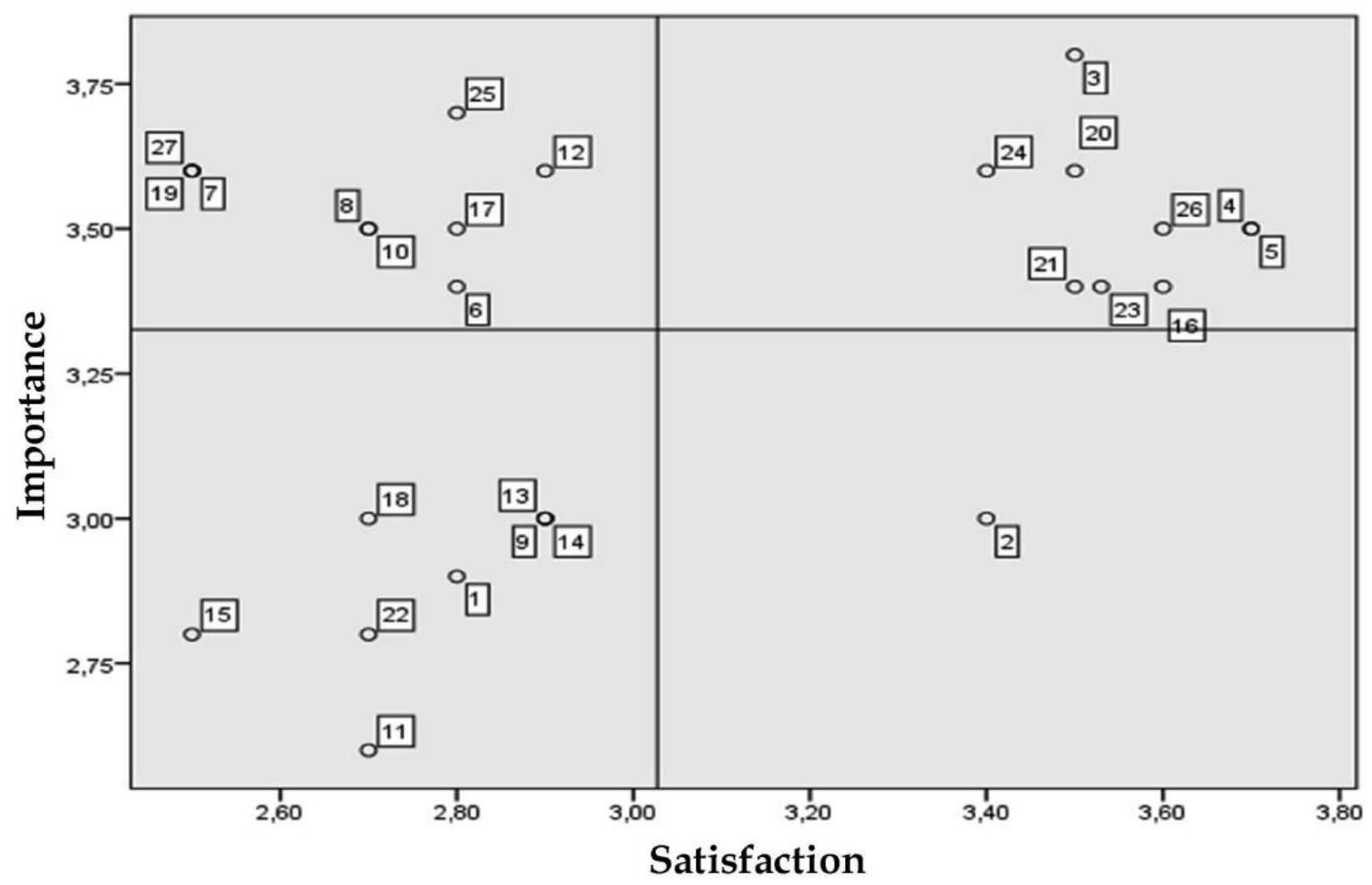

Figure 3. The Quadrants of Importance Performance Analysis (IPA) on Domestic Tourists Source: Primary Data (2019)

The quadrants components description of Importance Performance Analysis (IPA) on domestic tourists, which consisting of prices, physical facilities (infrastructures), and guarantees (services), as follows:

\section{Table 2. The Summary of Importance Performance Analysis (IPA) Quadrants on Domestic Tourists}

$\begin{array}{llc}\text { Components } & & \text { Quadrants } \\ \text { Prices } & \text { Tourism Package Prices } & \text { C } \\ & \text { Entrance Ticket Prices (Tourist Attraction) } & \text { D } \\ & \text { Food and Souvenir Prices } & \text { B } \\ & \text { Hotel/Home Stay Room Prices } & \text { B } \\ \text { Vehicle Rental Prices } & \text { B } \\ & \text { Flight Ticket Prices } & \text { A } \\ & \text { Extra Baggage Charges } & \text { A }\end{array}$

Copyright ( $(2020$. Owned by Author(s), published by Society. This is an open-access article under the CC-BY-NC-SA license. https://doi.org/10.33019/society.v8i1.157 


Physical
Facilities
(Infrastructures)

\section{Guarantees} (Services)
Variety of playground facilities (Tourist Attraction)

Availability of Souvenir gallery (Tourist Attraction)

Availability of Transportation Information to Tourist Attraction

Availability of Toilet and Worship Facilities (Tourist Attraction)

Availability of Tourism Map (Tourist Attraction)

Environmental Cleanliness (Tourist Attraction)

Security, Order, Safety Facilities (Tourist Attraction)

Comfort, Cleanliness of Stalls/Restaurants (Tourist Attractions)

Comfort, Cleanliness of Hotels/Homestay

Airport Convenience and Tourist Attraction Information at the Airport

Quality of Facilities and Infrastructures Maintenance

Availability of ATMs, Non-Cash Transactions and Money Changer

Local Specialty Foods

Photo Spots Location

Modern Shopping Center/Night Entertainment

The Beauty of Marine Tourism Objects

The Reality of the Tourism Packages compared to Promotions Offered

Communication Skills (Foreign Language) Officers and the Community

Community Hospitality and Services Officers

Cultural Attractions

A
C
A
C
A
C
C
C
B
A
C
A
B
B
C
B
B
A
B
A

Source: Primary Data (2019)

Based on the summary of the Domestic Tourists Importance Performance Analysis (IPA) quadrants, that:

1) Prices component: $28.57 \%$ in quadrant $A ; 42.87 \%$ in quadrant $B ; 14.28 \%$ in quadrant $C$; and $14.28 \%$ in the quadrant D.

2) Physical Facilities (Infrastructures): $33.33 \%$ in quadrant A; $20 \%$ in quadrant $B ; 46.67 \%$ in quadrant $\mathrm{C}$; and $0 \%$ in quadrant D.

3) Guarantees (Services): $40 \%$ in quadrant $A ; 60 \%$ in quadrant B; $0 \%$ in quadrant $\mathrm{C}$; and $0 \%$ in the quadrant D.

These results indicate that the 3 components have the components located in quadrant A, which is the quadrant of high importance but the level of satisfaction of domestic tourists is very low or tourists are dissatisfied. Among the three components, the guarantees (services) components have the highest percentage in quadrant A of $40 \%$. This means that domestic tourists want cultural attractions in the Tourism Attraction and want good communication from the public and services officers. The physical facilities (infrastructures) components have the highest components in quadrant $\mathrm{C}$, which is the quadrant with low importance and satisfaction. This means that improvements are needed to develop the physical facilities (infrastructures) such as maintenance of infrastructures, souvenir galleries, toilets, environmental cleanliness, restaurant cleanliness, and safety facilities.

\subsection{Results of Importance Performance Analysis (IPA) on Foreign Tourists}

Based on a questionnaire distributed to foreign tourists as respondents, the results obtained are as follows: 


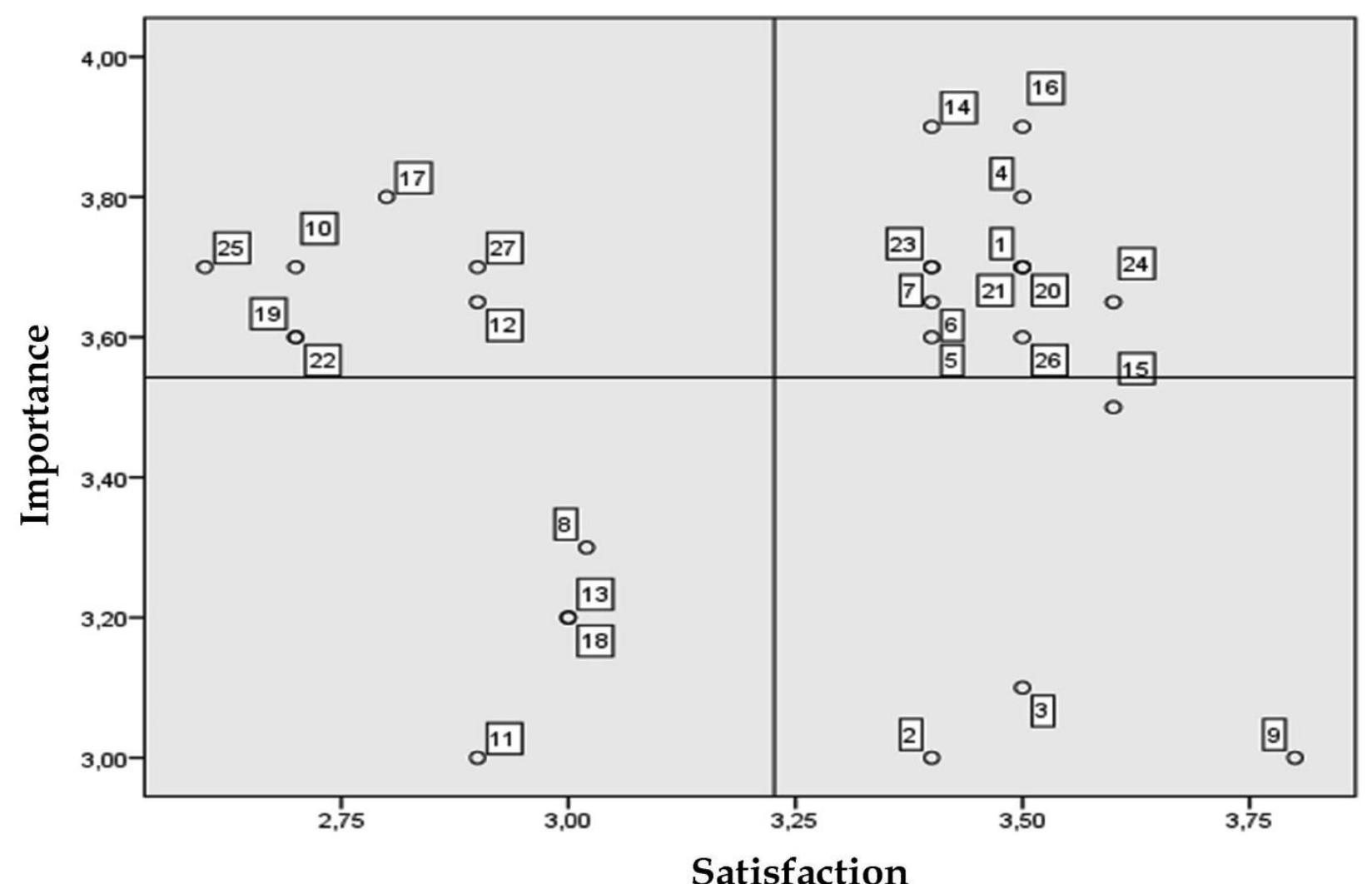

Figure 4. The Quadrants of Importance Performance Analysis (IPA) on Foreign Tourists Source: Primary Data (2019)

The quadrants components description of Importance Performance Analysis (IPA) on foreign tourists, which consisting of prices, physical facilities (infrastructures), and guarantees (services), as follows:

\section{Table 3. The Summary of Importance Performance Analysis (IPA) Quadrants on Foreign Tourists}

\begin{tabular}{llc}
\hline Components & \multicolumn{1}{c}{ Indicators } & Quadrants \\
\hline Prices & Tourism Package Prices & B \\
& Entrance Ticket Prices (Tourist Attraction) & D \\
& Food and Souvenir Prices & D \\
& Hotel/Home Stay Room Prices & B \\
& Vehicle Rental Prices & B \\
& Flight Ticket Prices & B \\
& Extra Baggage Charges & B \\
Physical & Variety of playground facilities (Tourist Attraction) & C \\
Facilities & Availability of Souvenir gallery (Tourist Attraction) & D \\
(Infrastructures) & Availability of Transportation Information to Tourist Attraction & A \\
& Availability of Toilet and Worship Facilities (Tourist Attraction) & C \\
& Availability of Tourism Map (Tourist Attraction) & A \\
& Environmental Cleanliness (Tourist Attraction) & C \\
& Security, Order, Safety Facilities (Tourist Attraction) & B \\
& Comfort, Cleanliness of Stalls/Restaurants (Tourist Attractions) & D \\
& Comfort, Cleanliness of Hotels/Homestay & B \\
& Airport Convenience and Tourist Attraction Information at the Airport & A \\
& Quality of Facilities and Infrastructures Maintenance & D \\
& Availability of ATMs, Non-Cash Transactions and Money Changer & A
\end{tabular}

Copyright ( $(2020$. Owned by Author(s), published by Society. This is an open-access article under the CC-BY-NC-SA license. https://doi.org/10.33019/society.v8i1.157 
Local Specialty Foods

Photo Spots Location

Modern Shopping Center/Night Entertainment

Guarantees

The Beauty of Marine Tourism Objects

(Services)

The Reality of the Tourism Packages compared to Promotions Offered

Communication Skills (Foreign Language) Officers and the Community

Community Hospitality and Services Officers

Cultural Attractions

Source: Primary Data (2019)

Based on the summary of the Foreign Tourists Importance Performance Analysis (IPA) quadrants, that:

1) Prices component: $0 \%$ in quadrant $A ; 71.43 \%$ in quadrant $B ; 0 \%$ in quadrant $C$; and $28.57 \%$ in quadrant $D$.

2) Physical Facilities (Infrastructures): $33.33 \%$ in quadrant $A ; 26.67 \%$ in quadrant $B ; 20 \%$ in quadrant C; and $20 \%$ in quadrant D.

3) Guarantees (Services): $40 \%$ in quadrant $A ; 60 \%$ in quadrant B; $0 \%$ in quadrant C; and $0 \%$ in the quadrant D.

These results indicate that only the price components are not in quadrant A. This means that the level of satisfaction of foreign tourists is very high for all prices of tourism packages offered. Among the physical facilities (infrastructures) and guarantees (services) components, the highest percentage value in quadrant $\mathrm{A}$ is the guarantees (services) components with a percentage of $40 \%$. This means that foreign tourists are not satisfied with the service of officers and community communication in foreign languages. Also, foreign tourists are dissatisfied with cultural attractions. Almost every tourist destination does not feature cultural attractions except for certain events. The physical facilities (infrastructures) components have the component in quadrant $C$ of $20 \%$. This means that foreign tourists want the variety of playgrounds at tourist destinations, and foreign tourists' satisfaction with environmental cleanliness is low.

\section{Conclusions}

Domestic tourists are dissatisfied with the guarantee component (service) which consists of cultural attractions and public communication in foreign languages and service officers. Furthermore, domestic tourists are dissatisfied with physical facilities (infrastructures) consisting of maintenance of facilities and infrastructure, souvenir galleries, toilets, environmental cleanliness, restaurant cleanliness, and safety facilities.

The level of satisfaction of foreign tourists is very high for all prices of tourism packages offered. However, foreign tourists are not satisfied with the service of officers and community communication in foreign languages. Also, foreign tourists want the variety of playgrounds at tourist destinations, and foreign tourists' satisfaction with environmental cleanliness is low.

\section{Acknowledgment}

The authors would like to thank the Institute for Research and Community Services of the University of Bangka Belitung for support and facilities for making this research success through Strategic Commodity Research in the Bangka Belitung Islands Province, funded by Bank Indonesia based on the Cooperation Letter Number 21/578/PkP/Srt/B, the funding year 
2019. The authors also wish to thank all informants who have provided help and information during this research conducted.

\section{Declaration of Conflicting Interests}

The authors declared no potential conflicts of interest with respect to the research, authorship, and/or publication of this article.

\section{References}

Alegre, J., \& Garau, J. (2010). Tourist Satisfaction and Dissatisfaction. Annals of Tourism Research, 37(1), 52-73. https://doi.org/10.1016/j.annals.2009.07.001

Aliman, N. K., Hashim, S. M., Wahid, S. D. M., \& Harudin, S. (2016). Tourists' Satisfaction with a Destination: An Investigation on Visitors to Langkawi Island. International Journal of Marketing Studies, 8(3), 173-188. https:// doi.org/10.5539/ijms.v8n3p173

Andriani, I. (2019). Integrasi transportasi dalam mendukung kawasan destinasi wisata Tanjung Kelayang Kabupaten Belitung. Jurnal Transportasi Multimoda, 16(1), 27-42. https://doi.org/10.25104/mtm.v16i1.835

Ariya, G., Wishitemi, B., \& Sitati, N. (2017). Tourism Destination Attractiveness as Perceived by Tourists Visiting Lake Nakuru National Park, Kenya. International Journal of Research in Tourism and Hospitality, 3(4), 1-13. https:/ / doi.org/10.20431/2455-0043.0304001

Armario, E. M. (2008). Tourist satisfaction: an analysis of its antecedents. In Universidad, Sociedad y Mercados Globales (pp. 367-382). Asociación Española de Dirección y Economía de la Empresa (AEDEM).

Aynalem, S., Birhanu, K., \& Tesefay, S. (2016). Employment Opportunities and Challenges in Tourism and Hospitality Sectors. Journal of Tourism $\mathcal{E}$ Hospitality, 5(6), 1-5. https:/ / doi.org/10.4172/2167-0269.1000257

Beldona, S., \& Cobanoglu, C. (2007). Importance-performance analysis of guest technologies in the lodging industry. Cornell Hotel and Restaurant Administration Quarterly, 48(3), 299-312. https:/ / doi.org/10.1177/0010880407304023

Bertan, S., \& Altintaş, V. (2013). Visitors' perception of a tourism destination: The case of Pamukkale. Tourismos, 8(1), 115-132.

Bigné, J. E., Sánchez, M. I., \& Sánchez, J. (2001). Tourism image, evaluation variables and after purhase behaviour: Inter-relationship. Tourism Management, 22(6), 607-616. https:/ / doi.org/10.1016/S0261-5177(01)00035-8

Bindu, T., \& Kanagaraj, D. C. (2013). Importance-performance analysis as a strategic tool for destination attractiveness: An analysis of domestic travelers to Kerala. International Journal of Management $\mathcal{E}$ Business Studies, 3(1), 61-67.

Blazeska, D., Strezovski, Z., \& Klimoska, A. M. (2018). The influence of tourist infrastructure on the tourist satisfaction in Ohrid. UTMS Journal of Economics, 9(1), 85-93. http:/ / utmsjoe.mk/files/Vol.\%209\%20No.\%201/UTMSJOE-2018-0901-08-

Blazeska_Strezovski_Milenkovska_Kimoska.pdf

Boley, B. B., McGehee, N. G., \& Tom Hammett, A. L. (2017). Importance-performance analysis (IPA) of sustainable tourism initiatives: The resident perspective. Tourism Management, 58(September 2018), 66-77. https:// doi.org/10.1016/j.tourman.2016.10.002

Bowen, D. (2002). Research through participant observation in tourism: A creative solution to the measurement of consumer satisfaction/dissatisfaction (CS/D) among tourists. Journal of Travel Research, 41(1), 4-14. https:/ / doi.org/10.1177/0047287502041001002 
Budiaji, W. (2013). Skala Pengukuran dan Jumlah Respon Skala Likert (The Measurement Scale and The Number of Responses in Likert Scale). Ilmu Pertanian Dan Perikanan, 2(2), 127-133.

Butcher, J. (2002). Flight to the sun: the story of the holiday revolution, by Roger Bray and Vladimir Raitz. Continuum, London, 2001. No. of pages: 246. Price $£ 16.99$ (hardback). ISBN 0-8264-4829-1. International Journal of Tourism Research, 4(6), 480-481. https:// doi.org/10.1002/jtr.360

Camilleri, M. A. (2018). Travel marketing, tourism economics and the airline product: An introduction to theory and practice. Cham: Springer. https:/ / doi.org/10.1007/978-3-319-49849-2

Chen, C. F., \& Tsai, D. C. (2007). How destination image and evaluative factors affect behavioral intentions? Tourism Management, 28(4), 1115-1122. https:/ / doi.org/10.1016/j.tourman.2006.07.007

Chi, C. G. Q., \& Qu, H. (2008). Examining the structural relationships of destination image, tourist satisfaction and destination loyalty: An integrated approach. Tourism Management, 29(4), 624-636. https:/ / doi.org/10.1016/j.tourman.2007.06.007

Chi, C. G. Q. (2011). Destination loyalty formation and travelers' demographic characteristics: A multiple group analysis approach. Journal of Hospitality $\mathcal{E}$ Tourism Research, 35(2), 191-212. https:/ / doi.org/10.1177/1096348010382233

Chu, R. K. S., \& Choi, T. (2000). An importance-performance analysis of hotel selection factors in the Hong Kong hotel industry: A comparison of business and leisure travellers. Tourism Management, 21(4), 363-377. https://doi.org/10.1016/S0261-5177(99)00070-9

De Nisco, A., Riviezzo, A., \& Napolitano, M. R. (2015). An importance-performance analysis of tourist satisfaction at destination level: Evidence from Campania (Italy). European Journal of Tourism Research, 10, 64-75.

Devy, H. A., \& Soemanto, R. B. (2017). Pengembangan Obyek Dan Daya Tarik Wisata Alam Sebagai Daerah Tujuan Wisata Di Kabupaten Karanganyar. Jurnal Sosiologi DILEMA, 32(1), 34-44. https:/ /jurnal.uns.ac.id/dilema/article/view/11194

Djeri, L., Stamenković, P., Blešić, I., Milićević, S., \& Ivkov, M. (2018). An importanceperformance analysis of destination competitiveness factors: case of Jablanica district in Serbia. Economic Research-Ekonomska Istrazivanja, 31(1), 811-826. https:// doi.org/10.1080/1331677X.2018.1456351

Firman, F. (2018). Analisis Data dalam Penelitian Kualitatif. https:/ / doi.org/10.31227/osf.io/q84ys

Fuchs, M., \& Weiermair, K. (2003). New perspectives of satisfaction research in tourism destinations. Tourism Review, 58(3), 6-14. https://doi.org/10.1108/eb058411

Fuchs, G., \& Reichel, A. (2006). Tourist destination risk perception: The case of Israel. Journal of Hospitality and Leisure Marketing, 14(2), 83-108. https://doi.org/10.1300/J150v14n02_06

Gujarati, D. N. (2003). Basic econometrics. New York: McGraw-Hill.

Gunawan, J., Wahab, N. A., \& Elmiati, E. (2016). Health Tourism in Belitung Indonesia: A SWOT Analysis. Belitung Nursing Journal, 2(2), 27-30. https:/ / doi.org/10.33546/bnj.12

Gursoy, D., Chi, C. G. Q., \& Karadag, E. (2013). Generational differences in work values and attitudes among frontline and service contact employees. International Journal of Hospitality Management, 32(1), 40-48. https://doi.org/10.1016/j.ijhm.2012.04.002

Haarhoff, R. (2018). Tourist perceptions of factors influencing destination image: A case study of selected Kimberley resorts. African Journal of Hospitality, Tourism and Leisure, 7(4), 1-21. https://www.ajhtl.com/uploads/7/1/6/3/7163688/article_27_vol_7_4_2018.pdf 
Jeng, C. R., Snyder, A. T., \& Chen, C. F. (2019). Importance-performance analysis as a strategic tool for tourism marketers: The case of Taiwan's Destination Image. Tourism and Hospitality Research, 19(1), 112-125. https:/ / doi.org/10.1177/1467358417704884

Kasnadi, K., \& Indrayani, R. (2019). Importance Of The Performance Analysis (IPA) And Customer Satisfaction For Determining The Service Strategies Through The Servqual Model Approach. Journal of Management and Business, 18(1), 25-31. https:// doi.org/10.24123/jmb.v18i1.352

Kleeman, G. (2001). Impacts of tourism. Geography Bulletin, 33(3), 66-69.

Kementerian Pariwisata Republik Indonesia. (2018). Rencana Strategis 2018-2019. Jakarta: Kementerian Pariwisata Republik Indonesia. http:/ / eperformance.kemenpar.go.id/dokumen/3Buku\%20RENSTRA\%2020182019_Revisi\%204_opt.pdf

Leung, Y. F., Spenceley, A., Hvenegaard, G., \& Buckley, R. (2018). Tourism and visitor management in protected areas: Guidelines for sustainability. Best Practice Protected Area Guidelines Series No. 27. Gland, Switzerland: International Union for Conservation of Nature and Natural Resources. https://dx.doi.org/10.2305/iucn.ch.2018.pag.27.en

Manafe, Janri. D., Setyorini, T., \& Alang, Y. A. (2016). PEMASARAN PARIWISATA MELALUI STRATEGI PROMOSI OBJEK WISATA ALAM, SENI DAN BUDAYA (Studi Kasus di Pulau Rote NTT). BISNIS: Jurnal Bisnis Dan Manajemen Islam, 4(1), 101-123. https://doi.org/10.21043/ bisnis.v4i1.1687

Molina, A., Gómez, M., \& Martín-Consuegra, D. (2010). Tourism marketing information and destination image management. African Journal of Business Management, 4(5), 722-728. https:/ / academicjournals.org/journal/ AJBM/article-full-text-pdf/D8C2F8423271

Panasiuk, A. (2007). Tourism infrastructure as a determinant of regional development. Ekonomika ir vadyba: aktualijos ir perspektyvos, 1(8), 212-215. http://www.su.lt/bylos/mokslo_leidiniai/ekonomika/7_8/panasiuk.pdf

Räikkönen, J. (2014). Enabling experiences - the role of tour operators and tour leaders in creating and managing package tourism experiences. Turku: Turku School of Economics.

Rajesh, R. (2013). Impact of Tourist Perceptions, Destination Image and Tourist Satisfaction on Destination Loyalty: A Conceptual Model. PASOS. Revista de Turismo y Patrimonio Cultural, 11(3), 67-78. https:/ / doi.org/10.25145/j.pasos.2013.11.039

Republik Indonesia. (2009). Undang-Undang Republik Indonesia Nomor 10 Tahun 2009 Tentang Kepariwisataan. Lembaran Negara Republik Indonesia Tahun 2009 Nomor 11. Jakarta: Kementerian Hukum dan Hak Asasi Manusia Republik Indonesia.

Ryglova, K., Vajcnerova, I., Sacha, J., \& Stojarova, S. (2015). The Quality as a Competitive Factor of the Destination. Procedia Economics and Finance, 34(15), 550-556. https:/ / doi.org/10.1016/s2212-5671(15)01667-6

Sörensson, A., \& von Friedrichs, Y. (2013). An importance-performance analysis of sustainable tourism: A comparison between international and national tourists. Journal of Destination Marketing and Management, 2(1), 14-21. https://doi.org/10.1016/j.jdmm.2012.11.002

Tureac, C. E., \& Turtureanu, A. (2010). Types and forms of tourism. Acta Universitatis Danubius. CEconomica, 4(1), 92-103. http://www.journals.univdanubius.ro/index.php/oeconomica/article/view/60

Utama, I. G. B. R. (2016). Pengantar Industri Pariwisata. Yogyakarta: Deepublish Yogyakarta CV Budi Utama.

Valeriani, D., \& Wardhani, R. S. (2015). Alternative Tourism in the Belitung Island with the Blue Tourism Concepts as the Effort to Achieve the Quality of Life, Quality of Opportunity and

Copyright (C) 2020. Owned by Author(s), published by Society. This is an open-access article under the CC-BY-NC-SA license.

https://doi.org/10.33019/society.v8i1.157

121 
Quality of Experience. Mediterranean Journal of Social Sciences 6(5), 46-51. https:// doi.org/10.5901/mjss.2015.v6n5s5p46

Valeriani, D., Dudetyo, D., \& Robiani, D. (2017). Tourism and Economic Growth of Bangka

Belitung Islands Province, Indonesia. IOSR Journal Of Economic and Finance, 8(4), 54-59. https:// doi.org/10.9790/5933-0804045459

Vengesayi, S., Mavondo, F. T., \& Reisinger, Y. (2009). Tourism destination attractiveness: Attractions, facilities, and people as predictors. Tourism Analysis, 14(5), 621-636. https:/ / doi.org/10.3727/108354209X12597959359211

Wilkins, H. (2010). Using importance-performance analysis to appreciate satisfaction in hotels. Journal of Hospitality Marketing and Management, 19(8), 866-888. https:// doi.org/10.1080/19368623.2010.514554

Wong, M. S., Hideki, N., \& George, P. (2011). The use of importance-performance analysis (IPA) in evaluating Japan's e-government services. Journal of Theoretical and Applied Electronic Commerce Research, 6(2), 17-30. https:// doi.org/10.4067/S0718-18762011000200003

Zaei, M. E., \& Zaei, M. E. (2013). The Impacts of Tourism Industry on Host Community. European Journal of Tourism Hospitality and Research, 1(2), 12-21. http://www.eajournals.org/wp-content/uploads/THE-IMPACTS-OF-TOURISMINDUSTRY-ON-HOST-COMMUNITY.pdf

\section{About the Authors}

1. Devi Valeriani, obtained her Doctoral degree in Economics from Sriwijaya University, Indonesia, in 2018. The author is an Assistant Professor at the Department of Economics, Faculty of Economics, University of Bangka Belitung, Indonesia.

E-Mail: $\underline{\text { deviyono92@gmail.com }}$

2. Aning Kesuma Putri, obtained her Master's degree in Economics from Sriwijaya University, Indonesia, in 2010. The author is an Assistant Professor at the Department of Economics, Faculty of Economics, University of Bangka Belitung, Indonesia.

E-Mail: putrianing@gmail.com 